\title{
A note on the performance of medium type turkeys fed on practical diets containing different levels of supplemental vitamins and trace minerals during the rearing period
}

\author{
J. Jankowski and A. Faruga \\ Department of Poultry Science, Olsztyn University of Agriculture and Technology \\ 10-718 Olsztyn 5, Poland
}

(Received 16 February 1996; accepted 12 April 1996)

\begin{abstract}
The influence of different contents of vitamins and minerals in practical diets on performance indices was evaluated on 300 medium type BUT-9 turkeys divided into two groups, 3 replicates, consisting of 25 toms and 25 hens in each.

Practical diets used in both groups differed only in the content of vitamins and trace minerals added: lower in group $\mathrm{L}$, higher in group $\mathrm{H}$.

The lurkeys of group $\mathrm{H}$ were characterized by a higher live body weight (females at 15 weeks by $-4.3 \%$, and males at 22 wecks - by $8.3 \%$ ), consumed less feed, crude protein and $\mathrm{AME}_{\mathrm{N}}$ per $1 \mathrm{~kg}$ of live body weight, lower mortality and carcass dressing percentage and breast muscle content. Toms of this group slaughtered at 22 weeks, had more leaf fat in the body.
\end{abstract}

KEY WORDS: turkeys, vitamins, trace minerals, performance

\section{INTRODUCTION}

A full expression of the genetic potential of turkeys is possible only when feed fully covers their nutritional needs. Due to a continuous and very fast breeding progress achieved in genetic improving of turkeys their nutrient needs should be currently updated (Benkova and Jankowski, 1995). This concerns also to vitamins and trace minerals added to feed mixtures (Nixey and Grey, 1989; Noy et al., 1994; Ward, 1993; Whitehead, 1995). In recent years higher, compared to 
the used so far, levels of vitamins and trace minerals for turkeys were recommended in the Nutrient Requirements of Poultry (1993).

The purpose of this investigation was to evaluate the influence of higher contents of vitamins and trace minerals in mixtures for young turkeys on their performance and carcass characteristics.

\section{MATERIAL AND METHODS}

The study was conducted in the experimental farm of the Olsztyn University of Agriculture and Technology from February to July 1995. The experiment was made on 300 medium-type BUT- 9 turkeys. The one-day old birds were divided at random into two groups ( $2 \times 150$ birds), 3 replicates, consisting of 25 toms and 25 hens in each.

Group L turkeys were fed with mixtures containing premixes of a lower contents of vitamins and trace minerals than those used in Poland up to date (IB-1 and IB-2), while group $\mathrm{H}$ birds were fed mixtures containing premixes of higher vitamin and trace minerals contents (IB-1S, IB-2S and IB-3S). The

TABLE 1

Vitamin and trace mineral supplementation per $1 \mathrm{~kg}$ of tested diets

\begin{tabular}{lccccc}
\hline Ingredient & IB1 & IB2 & IB-IS & IB-2S & IB-3S \\
\hline Vitamins: & & & & & \\
- A, IU & 9000 & 6000 & 15000 & 13000 & 12000 \\
$-\mathbf{D}_{3}, \mathrm{IU}$ & 1500 & 1300 & 4000 & 3000 & 2500 \\
$-\mathrm{E}_{\mathrm{m}} \mathrm{mg}$ & 15 & 10 & 40 & 35 & 25 \\
$-\mathrm{K}_{3}, \mathrm{mg}$ & 3 & 1.5 & 3 & 2.5 & 2 \\
$-\mathrm{B}_{1}, \mathrm{mg}$ & - & - & 2 & 1.5 & 1.2 \\
$-\mathrm{B}_{2}, \mathrm{mg}$ & 4 & 0.4 & 9 & 7.5 & 5 \\
$-\mathrm{B}_{6}, \mathrm{mg}$ & 0.4 & 0.5 & 4 & 3 & 2 \\
$\mathrm{~B}_{12}, \mathrm{mg}$ & 0.01 & 0.009 & 0.025 & 0.02 & 0.02 \\
Pantothenic acid, mg & 8 & 5 & 18 & 16 & 15 \\
Nicotinic acid, mg & 25 & 15 & 60 & 60 & 45 \\
Folic acid, mg & 0.2 & - & 1 & 1 & 0.08 \\
Biotin, mg & 0.05 & - & 0.2 & 0.15 & 0.10 \\
Choline chloride, mg & 300 & 200 & 800 & 700 & 600 \\
Manganese, mg & 50 & 40 & 120 & 120 & 100 \\
Zinc, mg & 30 & 60 & 60 & 60 & 50 \\
Iron, mg & - & - & 50 & 40 & 40 \\
Jodine, mg & 0.25 & 0.2 & 1.2 & 1 & 1 \\
Sclenium, mg & 0.1 & - & 0.3 & 0.3 & 0.3 \\
Copper, mg & - & - & 9 & 8 & 7 \\
Cobalt, mg & 0.4 & 0.4 & 1 & 0.7 & 0.5 \\
\hline
\end{tabular}


composition of the premixes was given in Table 1. Because of manganese deficiency frequently occuring in turkeys, amount of manganese in premixes used in group $\mathrm{H}$ was increased approximately $50 \%$, as compared to recommendations of Nutrient Requirements of Poultry (1993). Contents of zinc and folic acid were similar to NRC (1994) recommendations. Robenidin ( $33 \mathrm{mg} / \mathrm{kg}$ diet) was used in both groups as coccidiostat for first 3 weeks followed by Diclazuril (1 $\mathrm{mg} / \mathrm{kg}$ diet) from 4 th to 12 th week. Virginiamycin $(5 \mathrm{mg} / \mathrm{kg}$ diet) was a growth promotor in both groups till the age of 12 weeks.

The mixtures were composed of: wheat, barley, soyabean oil meal $(45 \%$ of $\mathrm{CP}$ ), meat-bone meal ( $55 \%$ of $\mathrm{CP}$ ), soyabean oil, poultry fat, dicalcium phosphate, limestone, sodium chloride, L-lysine and DL-methionine, and $1 \%$ of vitamin-mineral premix appropriate for a given age and group. Chosen indicators of the nutritive value of the mixtures during consecutive periods of rearing were shown in Table 2 . In order to make the investigation more accurate

TABLE 2

Calculated crude protein $(\mathrm{CP}), \mathrm{AME}_{\mathrm{N}}$ lysine and methionine content and the premix added in consecutive fattening periods

\begin{tabular}{|c|c|c|c|c|c|c|}
\hline \multicolumn{7}{|c|}{ Characteristic of feed mixtures } \\
\hline \multirow{2}{*}{$\begin{array}{l}\text { Age } \\
\text { weeks }\end{array}$} & \multirow{2}{*}{$\begin{array}{c}\text { Crude protein, } \\
\%\end{array}$} & \multirow{2}{*}{$\begin{array}{l}\mathrm{AME}_{\mathrm{N}}, \\
\mathrm{MJ} / \mathrm{kg}\end{array}$} & \multirow{2}{*}{$\begin{array}{c}\text { Lysine, } \\
\%\end{array}$} & \multirow{2}{*}{$\begin{array}{c}\text { Methionine, } \\
\%\end{array}$} & \multicolumn{2}{|c|}{ Premix added } \\
\hline & & & & & Group L & Group G \\
\hline $0-3$ & 28.0 & 11.91 & 1.75 & 0.63 & IB -1 & IB $-1 \mathrm{~S}$ \\
\hline $4-6$ & 25.0 & 12.12 & 1.60 & 0.60 & IB -1 & IB $-2 S$ \\
\hline $7-9$ & 23.0 & 12.13 & 1.40 & 0.56 & IB -1 & IB $-2 S$ \\
\hline $10-12$ & 21.0 & 12.75 & 1.30 & 0.53 & IB -1 & IB $-2 S$ \\
\hline $13-15$ & 18.0 & 13.17 & 1.10 & 0.50 & IB -2 & IB $-3 S$ \\
\hline $16-18$ & 15.5 & 13.17 & 0.95 & 0.46 & IB -2 & IB $-3 S$ \\
\hline $19-22$ & 14.5 & 13.17 & 0.85 & 0.42 & IB -2 & IB $-3 S$ \\
\hline
\end{tabular}

all components of each diet were mixed without premixes then divided into halves, premixes (IB or IBS) were added, and both batches of diets were again thoroughly mixed.

The turkeys of both groups were reared in the same building according to the technology used in the State Turkey Testing Station (Faruga and Puchajda, 1995). The birds were not given additionally any vitamins or minerals. The hens were slaughtered the age of 15 weeks and toms the age of 22 weeks. During the rearing period feed consumption and mortality were recorded weekly. All birds were weighed at the age of 12 and 15 weeks, toms also at the age of 18 and 22 weeks. For the above periods feed conversion ratio (FCR), as $\mathrm{kg}$ feed per $1 \mathrm{~kg}$ of body weight was calculated. 
At the age of 15 weeks 10 hens, and at the age of 22 weeks 10 toms from each group were slaughtered, and carcasses, after 24 hours of chilling, partially dissected. The content of breast and leg muscles and leaf fat was expressed as a percentage of live body weight (LBW).

The significance of differences between the groups was stated using $\mathrm{F}$ test.

\section{RESULTS AND DISCUSSION}

Live body weights and FCR of turkeys are shown in Table 3 . The difference in LBW was already evident at week 12 . Both toms and hens of group $\mathrm{H}$ were heavier than group L birds by $4.3 \%$ (hens) and $11.3 \%$ (toms). This difference increased at week 15 and amounted to $5.4 \%(0.39 \mathrm{~kg})$ in hens and $13.8 \%(1.38$ $\mathrm{kg}$ ) in toms. At week 22, toms fed a diet containing more vitamins and trace minerals were $8.3 \%(1.4 \mathrm{~kg})$ heavier than the birds fed a diet lower in these ingredients. At all periods, the difference in LBW was statistically significant $(\mathrm{P} \leqslant 0.01)$. LBW recorded in group $\mathrm{H}$ approximated the standard LBW for BUT turkeys (Faruga and Puchajda, 1995).

The more favourable body weight gains in group $\mathrm{H}$ turkeys were also reflected in a better utilization of feed nutrients and a lower consumption of the mixture (Table 3). Till week 15, turkeys of group $\mathrm{H}$ consumed on average $120 \mathrm{~g}$ of feed, 30 $\mathrm{g}$ of crude protein and $1.52 \mathrm{MJ} \mathrm{AME}_{\mathrm{N}}$ less per $1 \mathrm{~kg}$ of LBW than the birds of group L. Toms reared to the age of 22 weeks, consumed on average $210 \mathrm{~g}$ of feed $(6.9 \%), 50 \mathrm{~g}$ of crude protein $(8.1 \%)$ and $2.38 \mathrm{MJ} \mathrm{AME}_{\mathrm{N}}$ less per $1 \mathrm{~kg}$ of LBW $(6.2 \%)$, respectively.

A very good liveability of turkeys of both groups is noteworthy. During the first three weeks no poult mortality was observed, while till the age of 15 weeks

TABLE 3

Live body weight $(\mathrm{kg})$ of turkeys, and feed conversion ratio (FCR) $\mathrm{kg} / \mathrm{kg}(\bar{z} \pm \mathrm{SD}$ )

\begin{tabular}{|c|c|c|c|c|c|c|}
\hline \multirow{2}{*}{$\begin{array}{l}\text { Age } \\
\text { weeks }\end{array}$} & \multirow[t]{2}{*}{ Sex } & \multicolumn{3}{|c|}{ LBW } & \multicolumn{2}{|c|}{$\mathrm{FCR}^{2}$} \\
\hline & & Group L & Group H & Standard & Group L & Group H \\
\hline \multirow[t]{2}{*}{12} & 9 & $5.29^{\mathrm{A}} \pm 0.54$ & $5.53^{B} \pm 0.54$ & 5.91 & $2.33^{A} \pm 0.02$ & $2.22^{\mathrm{B}} \pm 0.02$ \\
\hline & $\vec{j}$ & $6.56^{\wedge} \pm 0.67$ & $7.39^{\mathrm{B}} \pm 0.67$ & 7.71 & & \\
\hline \multirow[t]{2}{*}{15} & q & $6.85^{\mathrm{A}} \pm 0.70$ & $7.24^{\mathrm{B}} \pm 0.70$ & 7.83 & $2.59^{\mathrm{B}} \pm 0.03$ & $2.47^{B} \pm 0.03$ \\
\hline & $\delta$ & $8.66^{\wedge} \pm 1.11$ & $10.40^{\mathrm{R}} \pm 0.86$ & 10.70 & & \\
\hline 18 & 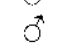 & $11.86^{\mathrm{A}} \pm 1.65$ & $13.48^{\mathrm{B}} \pm 1.25$ & 13.61 & $2.79^{\mathrm{A}} \pm 0.04$ & $2.63^{y} \pm 0.04$ \\
\hline 22 & 3 & $15.60^{\wedge} \pm 2.05$ & $17.00^{B} \pm 1.55$ & 17.28 & $3.05^{A} \pm 0.04$ & $2.84^{8} \pm 0.04$ \\
\hline
\end{tabular}

means in the same row with different superscripts differ significantly $(P \leqslant 0.01)$

1 - data BUT company

${ }^{2}-12$ and 15 weeks 0 
mortality amounted to $6.0 \%$ in group $\mathrm{L}$, and $4.0 \%$ in group $\mathrm{H}$. Total mortality among toms till the age of 22 weeks amounted to $9.9 \%$ in group $\mathrm{L}$ and $6.7 \%$ in group $\mathrm{H}$. The main cause of mortality in group $\mathrm{L}$ was cachexy and disbasia, while in group $\mathrm{H}$ it was circulatory system insufficiency.

While evaluating the performance of BUT-9 turkeys, Faruga and Puchajda (1995) recorded for hens a LBW of $8.0 \mathrm{~kg}$ and FCR $2.51 \mathrm{~kg}$ at the age of 15 weeks; for toms at the age of 22 weeks LBW was $17.1 \mathrm{~kg}$ and FCR $2.96 \mathrm{~kg} / \mathrm{kg}$. A similar body weight of BUT-9 hens at 15 weeks $(8.1 \mathrm{~kg})$ but better FCR $(2.12 \mathrm{~kg})$ was reported by Grashorn (1995).

:I:- :3its

TABLE 4

Some indications of the slaughter characteristics $(\bar{z} \pm$ SD) in $\%$ of LBW

\begin{tabular}{|c|c|c|c|}
\hline & \multirow{2}{*}{ Sex } & \multicolumn{2}{|c|}{ Groups } \\
\hline & & L & $\mathrm{H}$ \\
\hline \multirow[t]{2}{*}{ Carcass yield } & 오 & $79.4 \pm 1.9$ & $80.3 \pm 0.9$ \\
\hline & 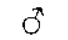 & $82.1 \pm 1.0$ & $84.2 \pm 2.1$ \\
\hline \multirow[t]{2}{*}{ Breast muscles } & Q & $21.7 \pm 1.1$ & $22.7 \pm 1.3$ \\
\hline & $\delta$ & $23.0^{\mathrm{a}} \pm 1.3$ & $24.7^{\mathrm{b}} \pm 1.4$ \\
\hline \multirow[t]{2}{*}{ Thigh muscles } & Q & $17.7 \pm 1.4$ & $17.8 \pm 1.3$ \\
\hline & $\delta$ & $20.0 \pm 1.4$ & $19.2 \pm 1.3$ \\
\hline \multirow[t]{2}{*}{ Leaf fat } & Q & $1.6 \pm 0.3$ & $1.6 \pm 0.4$ \\
\hline & $\sigma$ & $1.1^{2} \pm 0.4$ & $1.6^{b} \pm 0.5$ \\
\hline
\end{tabular}

means in the same row with different superscripts differ significantly $(\mathrm{P} \leqslant 0.05)$

The carcass yield and the content of breast muscles in the LBW (Table 4) both in hens and in toms fed on a diet of higher content of vitamins and trace minerals was higher than in birds of group L. However, a significantly higher leaf fat content was observed in toms of group $\mathrm{H}$.

\section{CONCLUSION}

The investigation has proved that an increased content of vitamins and trace minerals in mixtures for turkeys improves the performance indices. Turkeys fed with mixtures of a higher content of vitamins and trace minerals were characterized by a higher body weight, a more advantageous use of nutrients, better liveability and a higher carcass dressing percentage. 


\section{REFERENCES}

Benkova J., Jankowski J., 1995. Breeding strategy in turkey. Proceedings of the 11 th Symposium on Current Problems in Avian Genetics, Kraków, pp. 98-105

Faruga A., Puchajda H., 1995. Report from the rearing of market turkeys. State Station of Turkey Testing, Olsztyn (manuscript).

Grashorn M.A., 1995. Growth and slaughter characteristics of different turkey lines. Proceedings of the 12th European Symposium on the Quality of Poultry Meat, Zaragoza, pp. 157-164

National Research Council, 1994. Nutrient Requirements of Poultry. 9th ed. National Academy Press, Washington, D. C., pp. 35-39

Nixey C. and Grey T.C., 1989. Recent Advances in Turkey Science. Butterworth Ltd. Kent, pp. 183-199

Noy Y., Frisch Y., Rand N., Sklan D., 1994. Trace mineral requirements in turkeys. World Poultry Sci. J., 50, pp. 253-268

Nutrient Requirements of Poultry, 1993. Nutritive value of feeds (In Polish). 2nd ed. The Kielanowski Institute of Animal Physiology and Nutrition (Editor), Jablonna pp. 35-44

Ward N.E., 1993. Vitamin supplementation rates for U.S. commercial broilers, turkeys, and layers. J. Appl. Poultry Res. 2, 286-296

Whitehead C.C., 1995. Current knowledge on vitamin requirements of poultry. Proceedings 10th European Symposium On Poultry Nutrition, Antalya, 64-73

\section{STRESZCZENIE}

Wpływ zawartości witamin i mikroelementów w mieszankach paszowych na wyniki odchowu i wydajność rzeźną indyków

Wplyw zwiększonej zawartości witamin i mikroclementów w mieszankach na wyniki odchowu i wydajność rzeźną oceniono w doświadczeniu na 300 indykach średniociężkich BUT-9 podzielonych na dwie grupy, z których każda składa się z 3 podgrup o liczebności 25 indorków i 25 indyczek. Mieszanki stosowane w obu grupach różnily się jedynie zawartością witamin i mikroelementów, która była niższa w grupie L, wyższa w grupie $\mathrm{H}$.

Indyki $\mathrm{z}$ grupy $\mathrm{H}$ charakteryzowaly się większą końcową masą ciała (samice w wieku 15 tygodni o 4,3\%, a samce w wieku 22 tygodni o 8,3\%), zużywaly mniej paszy, bialka ogólnego i $\mathrm{AME}_{\mathrm{N}}$ na $1 \mathrm{~kg}$ masy ciała, lepszą przeżywalnością i wydajnością rzeźną oraz większą zawartością mięśni piersiowych. Indory z grupy H, ubijane w wieku 22 tygodni, odkładały więcej tłuszczu sadelkowego. 